\title{
RESENHA
}

\section{Topologia da violência: reflexões para pensar a sociedade contemporânea}

\author{
Alcemira Maria Fávero' \\ Professora na Universidade de Passo Fundo \\ Camila Fávero² \\ Atriz de teatro
}

Apesar de ser uma prática tão antiga quanto a espécie humana, a violência com certeza continuará sendo um tema instigante sobre o qual precisamos pensar, estudar, investigar, refletir e escrever. Dentre as coisas que nunca desaparecem, a violência certamente pode ser incluída e por isso constitui assunto/tema/problema da antropologia, filosofia, política, psicologia, história, sociologia, economia, literatura e educação. Sua forma de aparição varia segundo a constelação social. Na atualidade, ela tem se modificado de visível para invisível, de frontal para viral, de direta para mediata, de real para virtual, de física para psíquica, de negativa para positiva, e se retira para os espaços subcomunicativos e neuronais, de tal maneira que pode dar a impressão de que desapareceu. Porém, um olhar mais apurado possibilita perceber que ela se mantém constante, presente, invisível.

A obra Topologia da Violência ${ }^{3}$ do filósofo Byung-Chul Han (2016) constitui um precioso escrito para analisar o tema da violência em suas múltiplas faces. A leitura dessa obra constitui uma aprendizagem ímpar. Não havíamos, ainda, lido algo com essa compreensão da violência. Han consegue nos fazer participar de sua reflexão em razão da clareza com que aborda o tema. Se compreendermos o modo como a experimentamos e as múltiplas faces pelas

\footnotetext{
Mestre em Educação pela Universidade Federal do Rio Grande do Sul; Especialista em Metodologia do Ensino de Filosofia pela Universidade de Passo Fundo.

2 Graduada em Artes Cênicas pela Universidade do Estado do Paraná.

3 Utilizamos uma tradução espanhola da obra de Byung-Chul Han (do original é Topologie der Gewalt) publicada em Berlim em 2013. Optamos por traduzir para o português as citações feitas na presente resenha.
} 
quais ela se constitui ao nosso redor, talvez possamos não somente fazer dela nosso objeto de estudos, mas mudar os contornos da vida.

Byung-Chul Han, nascido na Coreia do Sul em 1959, estudou Literatura alemã e teologia na Universidade de Munique (Alemanha) e Filosofia na Universidade de Friburgo/Alemanha, onde também se doutorou em 1994 com uma tese sobre Martin Heidegger. Na atualidade é professor de Filosofia e Estudos Culturais da Universidade de Artes de Berlim. É autor de mais de uma dezena de qualificados Ensaios dentre os quais está Topología de la Violência, objeto da presente resenha. $\bigcirc$ Ensaio é composto de 13 capítulos, divididos em duas partes: a primeira, intitulada Macrofísica da Vilência, é composta de cinco capítulos; a segunda, intitulada Microfísica da Violência, é composta de oito capítulos.

No capítulo Topologia da Violência (capítulo l da primeira parte) Han trata dos deslocamentos fundamentais da violência ocorridos na cultura ocidental. Na cultura antiga, entre os gregos, a tortura era algo indispensável e por isso temos uma sociedade sangrenta. A mitologia, por exemplo, é repleta de sangue, em que a violência era uma espécie de espetáculo em praça pública, um teatro da crueldade. Na Roma antiga havia dentre as práticas de violência (execuções pelo fio da espada e pela fogueira) a luta de gladiadores que não significava somente entretenimento, mas a liberação da pulsão da morte. A violência era sinônimo de poder e dominação e por isso a sua exposição como comunicação social. $\bigcirc$ governo se valia da simbologia do sangue.

Na modernidade a violência se retira do cenário da exibição pública e muda de lugar; passa do visível para o invisível e por isso há uma troca cultural da violência. As execuções ocorrem em lugares sem acesso público. A pena de morte deixa de ser exibição, configurando-se um extermínio surdo e mudo.

Na modernidade o "vírus digital da violência" se dedica mais em infectar do que atacar. Han denomina violência da negatividade (p. 19), pois se constitui numa dualidade (bipolaridade) entre vítima e executor, bem e mal, amigo e inimigo. Trata-se de um deslocamento topológico fundamental, pois a violência física se interioriza tomando a forma de um conflito interior, um 
domínio psíquico que se apropria do sujeito. Ordem e dominação vigem sem nenhum esforço físico e material. A coação externa cede lugar para a coação interna que se apresenta como liberdade. Esse é o espírito do capitalismo, pois a autoexploração é muito mais eficiente, muito mais potente do que a exploração do outro. A violência da exploração capitalista oferece a sensação de liberdade. Autoagressividade (violência contra si mesmo) que em muitas ocasiões acaba em suicídio.

No Arqueologia da Violência (capítulo 2 da primeira parte, p. 23-39) Han inicia apresentando a tese de Freud de que existe uma pulsão da morte que origina os impulsos destrutivos e, de imediato cita René Girard, que ao contrário de Freud, afirma que a violência é uma rivalidade mimética. Desejar ter o que o outro possui. Segundo Girard, "a rivalidade mimética é a fonte principal da violência humana" (p. 23). Han concorda com Girard de que a mimese é uma das formas principais de formação do comportamento humano, mas discorda da ideia de "rivalidade mimética" em relação à violência, pois se deseja as coisas por uma necessidade primaria ou porque a coisa representa um valor para sobrevivência, uma luta contra os medos e principalmente contra a morte.

Para Han, os objetos possuem um valor intrínseco, por exemplo, o dinheiro. No capitalismo, quanto mais dinheiro (violência) mais poder. Muitos trabalham para um. $\bigcirc$ acúmulo de dinheiro é uma defesa contra a morte, pois o capital infinito gera uma ilusão de tempo infinito. Para sustentar essa tese, Han compara características das sociedades arcaicas com a modernidade. Apresenta a violência como um meio central de comunicação religiosa, a necessidade da morte para tratamento contra a violência e a demonstração de que ela enquanto sacrifício é promotora de desenvolvimento, força e poder. $\mathrm{Na}$ morte ninguém mata para imitar a outrem. A morte é sempre violenta. E não importa dizer que é natural ou não. No quesito religioso o sacrifício também é uma forma de violência, e isso foi desde os povos primitivos até a atualidade. Chega-se ao Deus na violência por meio dela.

$\mathrm{Na}$ modernidade, características similares às sociedades arcaicas estão muito presentes. Poder-se-ia comparar o "mana" (substância poderosa que traslada da vítima para o vencedor - guerreiro bravo) com a potência 
de destruição atômica que gera o sentimento de poder e invulnerabilidade. Além disso, o capital também se comporta como o "mana" moderno. Quanto mais posse, mais poderoso, invencível e imortal. Por fim, afirma o autor, a preocupação com a boa vida dá lugar à histeria pela sobrevivência. "A vida nunca tem sido tão efêmera quanto hoje." (p. 38). Uma sociedade governada pela sobrevivência é uma sociedade de zumbis que não são capazes de viver nem de morrer (p. 39).

No capítulo O Psiquismo da Violência (capítulo 3 da primeira parte), Han trata de uma violência cuja morada é psíquica. Trata-se da autoagressividade gerada pelo combate do "eu real" com o "eu ideal". Uma guerra contra si mesmo. Enfermidades psíquicas como a síndrome de burnout e a depressão mostram todas as características de uma violência autogerada. Em Freud, ao tratar da sociedade disciplinar, Han destaca o poder do Super ego sobre o ID. O caráter como fenômeno da negatividade porque é "um resíduo das cargas do objeto abandonadas." (p. 52). O sujeito na psicanálise freudiana é alguém que atua por dever e obrigação. Também em Kant essa máxima vai preponderar, pois o sujeito do dever oprime todas as inclinações prazerosas em prol das virtudes, e como recompensa o "deus moral" o gratifica. Mas Han adverte que talvez estejamos já há algum tempo nos afastando dessa realidade, pois o sujeito da modernidade tardia é pobre em negação e não se dedica ao trabalho por dever ou obrigação e, sim, pela liberdade, prazer e entretenimento. Um sujeito empresário de si mesmo. Porém, essa libertação do outro conduzirá esse sujeito a uma relação narcisista.

Han conclui $O$ Psiquismo da Violência ressaltando que as enfermidades psíquicas da atualidade apontam para um excesso de positividade, quer dizer "não ao dever", "não à negação" e sim a um "poder tudo". Por isso a psicanálise não representa uma saída para os "melancólicos" e "depressivos" dos nossos dias. Um sujeito pobre em alteridade e que se encontra cansado e atormentado consigo mesmo. Citando Alain Ehrenberg, Han afirma: um sujeito narcisista que dispõe de um excesso de opções, mas incapaz de vínculos intensos. "Na depressão desmoronam todos os vínculos, inclusive consigo mesmo." (p. 56). $\mathrm{Na}$ sociedade do rendimento o sujeito trava batalhas diárias consigo mesmo e cai na compulsão destrutiva de superar a si mesmo. Não se trata de vencer 
o outro, mas vencer a si mesmo. "A nefasta competência que busca superar a própria sombra." (p. 61).

No Capítulo dedicado à Política da Violência (capítulo 4 da primeira parte), Han inicia citando Carl Schmitt, o qual defendia a tese de que a essência do político se sustenta na distinção amigo e inimigo. Essa dualidade não é um sistema, mas um domínio. Uma comunidade se torna política quando se vê ameaçada por inimigos. Para Schmitt, a política se desenvolve numa comunidade por sentimentos ou questões existenciais. Não é por questões econômicas que se faz inimigos, pois na economia há competidores. Os inimigos são identificados na política. É na comunidade que se decide destruir o inimigo. Sem um inimigo não há motivação para lutar.

Para Han a "política daidentidade" de Schmittlibera energias destrutivas, porque tanto para fora quanto para dentro se precisa encontrar o inimigo. "A violência que converte o outro em inimigo confere firmeza e estabilidade do eu." (p. 72). Como se o "eu" se clarificasse com mais nitidez à medida que o inimigo estivesse também mais clarificado, ou seja, definindo-se a figura do inimigo define-se o eu. $\bigcirc$ inimigo construído imaginariamente ajudaria o eu a aliviar-se da constante guerra consigo mesmo. Para Han, é preciso libertar-se dessa "roda de hamster" que dá volta sobre si mesmo e estabelecer uma relação com o outro para além do esquema schmittiano. "Deveria ser possível uma relação com o outro na qual o eu permitiria e afirmaria sua diversidade, seu jeito de ser. Esse seu jeito de ser se chama amizade." (p. 76).

Na continuidade de suas reflexões sobre A Política da Violência, Han, citando Hegel e Walter Benjamin, escreve sobre a relação entre “Direito e violência". Para os dois autores, existe uma unidade profunda entre direito e violência. $\bigcirc$ direito está a serviço do poder e para sua eficácia é inseparável da violência. Precisa-se do direito porque há falta de confiança e na desconfiança a violência entra em cena. Benjamin questiona: "os indivíduos em conflitos de interesses podem chegar a um acordo por outro meio que não seja a violência?" (p. 83). Para ele, sim, desde que se libertem de toda relação jurídica. Os meios limpos e não violentos se vinculam quando há cortesia sincera, afinidade, amor a paz e confiança (p. 89). 
Em Aristóteles, Han intensifica a discussão em torno da amizade. Porque o filósofo eleva a amizade como o mais importante dos bens para a cidade. Na "política da amizade" a opção é pela vida em comum. Para finalizar esse tópico Han cita G. Agamben, afirmando que apesar de este viver numa sociedade pós "imunológica" ou "sociedade disciplinar" segue no paradigma da negatividade, pois compreende a violência como exclusão e inibição. Para Agamben, o "direito e a violência" se coincidem por completo, e a política está contaminada pelo direito. Em sua reflexão, segundo Han, Agamben perde de vista a violência da positividade por estar ainda fascinado pelas figuras políticas, e, na atualidade, essas figuras políticas estão envoltas no brilho do espetáculo midiático. "A política do espetáculo é uma política do vício comunicativo." (p. 99). A publicidade se apresenta como a cara bonita da dominação que serve ao capital cujo objetivo é o consumo.

Ao tratar da Macrologia da Violência (último capítulo da primeira parte), Han se dedica a caracterizar e diferenciar "poder e violência" e "macrofísica e microfísica" da violência. Na macrofísica da violência existe uma tensão entre o "ego e o outro", entre o "amigo e o inimigo", entre o "exterior e o interior". Sua principal característica é a infiltração e a invasão. A violência macrofísica é uma influência exterior que ataca e rouba a liberdade. Segundo Han, "toda" influência externa desconhecida é violência. Porém, deixa de ser quando ocorrer a interiorização, quando o sujeito estabelece uma relação com ela. Se isso não ocorrer permanece como um trauma e segue violência, mas como algo fora do eu, embora sempre gerando a tensão entre o interno e o externo. "Se mostra como uma des-interiorização do interior através do interior." (p. 102). Segundo Han, a violência é sempre destrutiva, enquanto o poder une e engaja. Poder não é sinônimo de violência. "O poder se inclina para o outro até dobrá-lo, até engajá-lo e a violência se inclina até quebrá-lo." (p. 103). O poder não impede o espaço de atuação e nem exclui totalmente a liberdade. sujeito sempre pode recorrer à desobediência. Pode rebelar-se contra a vontade do poderoso. Mas a violência destrói a atuação e a liberdade. Han assume que tanto a violência quanto o poder são estratégias para neutralizar a inquietude da otredad e sua sede de liberdade, mas o poder, ao contrário da 
violência, não aniquila o outro. $\bigcirc$ poder, enquanto meio de atuação, pode ser usado de modo construtivo, a violência, por sua vez, é destrutiva em si mesma.

Para Han, é possível adquirir o poder por meio da violência, mas é um poder frágil. "É um erro pensar que o poder remete à violência. A violência tem uma intencionalidade completamente distinta do poder." (p. 107). Tanto a macrofísica da violência quanto o poder "do soberano" são fenômenos da negatividade. Na atualidade "poder e violência" não representam um meio fundamental para política. "Com a positivisação da sociedade, também o poder, como meio socioimunológico, perde cada vez mais significação." (p. 1 10). Não significa o fim da "violência", mas um novo tipo de violência porque esta não se manifesta somente na negatividade do outro, mas também na positividade. Da macrofísica para a microfísica. "A violência macrofísica destrói toda a possibilidade de ação e atividade. Suas vítimas são jogadas em uma passividade radical. A destrutividade da violência microfísica, ao contrário, tem sua origem no excesso de atividade que se manifesta como hiperatividade." (p. 112). O outro não é mais o inimigo, mas o competidor. Este não gera nenhuma reação imune. A micrológica da violência que será explorada na segunda parte desse livro é uma lógica do igual. "E o terror do igual." (p. 113).

Han inicia sua análise da Microfísica da Violência (segunda parte do livro) tratando da Violência Sistêmica (Capítulo 1), pois acredita que a situação em que ocorre um ato violento tem sua origem no sistema, "na estrutura sistêmica em que se integra", em que "as formas de violência manifestas e expressivas remetem a uma estrutura implícita" que escapa à visibilidade (p. 117). No entanto, Han chama a atenção dizendo que a violência estrutural não pode ser confundida com todas as "condições sociais negativas", como a injustiça social. "A violência estrutural não é violência no sentido estrito", e sim "uma técnica de dominação", pois permite que haja uma dominação discreta, "que é muito mais eficiente que uma dominação violenta." (p. 118).

Na interpretação de Han, a "violência sistêmica" de Bourdieu também se localiza no interior do sistema social. "A violência simbólica, sem necessidade de violência física, se ocupa de que se perpetue a dominação", pois a afirmação e a perpétua relação de dominação são feitas por costume na cotidianidade. Assim se "consolida a relação de dominação com grande eficácia, porque a 
mostra como natureza, como um fato, um é-assim, que nada pode por dúvida." (p. 1 19). Na avaliação de Han, Bourdeiu não faz uma distinção clara entre poder e violência, tomando-os "quase como sinônimos". Para Han, apesar de serem parecidos, "há uma diferença estrutural", pois a dimensão simbólica do poder se ocupa de que o domínio se exerça também sem violência." (p. 1 19).

Han também aborda a "violência objetiva" de Zizek, quando este se refere a "uma 'violência social-simbólica', que a ideologia transforma em um fato natural, que se aceita previamente" e que gera "as mais sutis formas de coerção que impõem relações de dominação e exploração." (p. 120121). No entanto, Han destaca que para Zizek lhe passa "despercebido que a violência sistêmica, que tem lugar sem uma dominação, que implica uma autoexploração, é uma violência que não só afeta uma parte da sociedade, mas toda ela." (p. 122). A título de exemplo cita a "sociedade de rendimento ocidental", que exerce uma pressão que subjuga não só as mulheres e a classe dirigente, mas a todos os seus membros. A violência sistêmica, para Han, é uma violência da positividade, pois "não está dotada da negatividade do obstáculo, da rejeição, da proibição, da exclusão ou da supressão"; ela se manifesta como "abundância e massificação, como excesso, exuberância e exaustão, como hiperprodução e hiperinformação." (p. 123). Trata-se, portanto, de uma violência que gera uma "bulimia psíquica", de uma "violência da positividade" que gera os transtornos neuronais que se manifestam "na depressão ou no burnout." (p. 124).

Ao tratar da Microfísica do Poder (Capítulo 2 da Segunda Parte), Han toma como base de análise a teoria do poder de Foucault, segundo a qual "o poder já não se manifesta como o poder de morte do soberano e sim como um poder disciplinário e biopolítico." (p. 127). Na microfísica do poder não ocorre mais "o poder da espada", representada pelo soberano, que simboliza "a potência de morte"; ao contrário, "o poder disciplinário" atua na direção "de controle, de vigilância, de aumento e organização de forças que submete", a fim de possibilitar "a administração dos corpos e a gestão calculadora da vida" (p. 127). No entanto, ressalta Han, "a biopolítica como tal" não é "um poder-político", pois "a técnica disciplinar não é uma expressão imediata do poder e do governo, mas sim uma práxis social generalizada." (p. 128). "A 
modernidade", reforça Han, "tem lugar uma difusão ou uma dispersão do poder, um 'desempoderamento' crescente do poder." Isso levou Foucault "a definir o próprio poder como 'não-subjetivo', como meramente estrutural, como uma 'multiplicidade das relações de força', 'próprias do domínio em que se exercem, e que são constitutivas de sua organização'." (p. 130).

Na interpretação de Han, "a sociedade disciplinar de Foucault, feita de prisões, hospitais, centros penitenciários, casernas e fábricas já não é um reflexo da sociedade contemporânea." (p. 135). A sociedade disciplinar teorizada por Foucault deu lugar a "uma sociedade de rendimento." Ao contrário "do sujeito de obediência" próprio da sociedade disciplinar, "o sujeito de rendimento é livre", "sua existência está regida pela liberdade e pela iniciativa"; porém, essa liberdade se transforma em coação, em "autoexploração". "O sujeito de rendimento se explora a si mesmo até desmoronar-se" e por isso que "a violência e a liberdade são o mesmo", "a violência se dirige a si mesmo", "o explorador é o explorado", "o executor coincide com sua vítima" e "o burnout é a forma de aparição patológica dessa liberdade paradoxal." (p. 135). Han conclui o capítulo dizendo que "a violência da positividade é mais traidora que a violência da negatividade, posto que esta se oferece como liberdade." Da "violência da decapitação" da sociedade pré-moderna da soberania, passamos para a violência da "deformação" da sociedade moderna disciplinar" e chegamos agora à "violência da positividade que não permite distinguir entre liberdade e coação", e "sua manifestação patológica é a depressão." (p. 136).

No início do capítulo dedicado à Violência da Positividade (capítulo 3) Han ressalta que "o desmoronamento da negatividade faz com que surja um excesso de positividade, de promiscuidade generalizada, de consumo, de comunicação, de informação e produção." (p. 137). Valendo-se dos escritos e reflexões de Baudrillard, denuncia que "o espaço ascético da positividade, ao ter eliminado o efeito de toda negatividade imunológica do outro, desenvolve novas formas de viralidade, uma nova patologia." (p. 138). Para Han, a época contemporânea não é mais "uma época viral", "as enfermidades principais não são infecções virais ou bacterianas, mas sim são enfermidades psíquicas como o bournout, a hiperatividade ou a depressão, que não se remetem à negatividade viral, senão ao excesso de positividade, à violência da positividade." (p. 140). 
Na violência da positividade, não existe um inimigo externo, pois "a falta de negatividade da inimizade faz com que a guerra se dirija contra si mesmo", ou seja, "quem destrói, será destruído"; "quem golpeia, será golpeado"; "quem vence, perde por sua vez." (p. 141). Trata-se, portanto, de uma guerra em que nada se pode ganhar, onde não há vencedor. A violência da positividade é "implosiva", diferente da violência da negatividade, que é "explosiva". Enquanto "a violência explosiva exerce uma pressão que vem de fora", a violência implosiva exerce uma pressão de dentro "que causam tensões e impulsos destrutivos"; "o bournout do sujeito de rendimentos é um signo da ameaça de implosão do sistema." (p. 142). "A erosão do social cada vez maior" da sociedade contemporânea acaba produzindo "egos ilhados encerrados em si mesmo." Para Han, "muito mais perigoso que o terror do outro é o terror de si mesmo, o terror da imanência", pois "já não é possível defender-se com eficácia deste porque já não há negatividade." (p. 144).

Han inicia sua análise sobre a Violência da Transparência (Capítulo 4) dizendo que "a necessidade onipresente de transparência aponta para uma constelação dominada por um excesso de positividade, que reduz a negatividade cada vez mais." A transparência está associada a uma série de outros fenômenos contemporâneos, como "a hipercomunicação, a hiperinformação e a hipervisibilidade." (p. 149). Han demostra que há certas situações em que a transparência não pode ser colocada em termos absolutos. Os espaços sagrados, as experiências religiosas, a fé, a confiança e mesmo o pensamento são situações em que a transparência não pode se efetivar plenamente.

"A exigência permanente de transparência", ressalta Han, "se baseia em uma ideia de mundo, em uma ideia de homem que está livre de toda forma de negatividade. Porém só as máquinas são absolutamente transparentes. Uma comunicação transparente seria uma comunicação mecânica que não teria necessidade do homem para nada." (p. 150-151). É nesse aspecto que reside a violência da transparência e se torna violência por fazer "desaparecer o outro por completo sob a luz do idêntico. [...] A violência da transparência se expressa como nivelação do outro até convertê-lo em idêntico, como supressão da outridade. [...] A política da transparência é uma ditadura do idêntico." (p. 151). 
No final do capítulo dedicado à violência da transparência, Han denuncia que na sociedade da transparência contemporânea "a exibição pornográfica e o controle panóptico se transforma no mesmo." As redes sociais se tornaram o "panóptico eletrônico", em que a sociedade de controle se concretiza quando o sujeito se expõe por completo, "quando o medo de perder sua esfera íntima privada dá lugar à obrigação de expor-se indecentemente." (p. 156). Não é mais o panóptico da sociedade disciplinar que está em ação, mas, sim, o panóptico da sociedade de rendimento e de consumo que "não tem mais correntes, nem fortificações, nem espaços fechados", mas "google e outras redes sociais como Facebook" que se tornaram "panópticos digitais dos serviços secretos." (p. 156). Nesse novo panóptico o controle não se apresenta como um "ataque à liberdade", mas como um usuário que se entrega "por vontade própria à visão panóptica." (p. 157).

Han inicia O meio é Mass-Age (capítulo 5 da segunda parte) dizendo que "a linguagem é um meio de comunicação", e como qualquer meio "se expressa tanto de um modo simbólico como diabólico." (p. 159). O lado simbólico da linguagem é "relacional", "construtivo", "comunicativo"; o lado diabólico apresenta "os traços destrutivos" da linguagem. Os aspectos simbólico e diabólico da linguagem ainda correspondem ao "esquema imunológico" em que "Toda linguagem de violência que se refere a difamação, desacreditação, degradação, desautorização, ou inclusive à reificação, é uma violência da negatividade", pois implica a "negação do outro". Porém, a nova violência da linguagem "não é negativa, mas sim positiva", pois "não se dirige contra o outro", e sim "surge da massa do igual, da massificação do positivo." (p. 160).

Nesse processo de "massificação do positivo" ocorre a hipercomunicação, que gera uma "spanização da linguagem e da comunicação." (p. 160). A hipercomunicação, por sua vez, "incrementa a entropia do sistema de comunicação" e "gera o lixo comunicacional e linguístico" (p. 165) que se manifesta por meio da "harmoniosa publicidade que tem como objetivo capturar a atenção." (p. 166). Trata-se de "um lixo positivo", que não tem a função de afastar o outro e sim "pretende ser agradável e atrativa" para "incluir" (p. 167). Han conclui o capítulo dizendo que "a massa de comunicação, informação e signos gera uma violência particular, uma 
violência da positividade, que já não ilumina nem revela, mas que somente atua massivamente." Trata-se da "massa positiva sem mensagem que dispersa, embrutece e paralisa." (p. 169).

No capítulo dedicado à Violência Rizomática (capítulo 6 da segunda parte), Han ressalta que "a violência não surge unicamente da hipercodificação", mas também "da descodificação desmensurada e da supressão de fronteiras, que dissolve o mundo em uma torrente incontrolável de acontecimentos, impulsos e intensidades." (p. 171). Han analisa esse tipo de violência tendo Deleuze como interlocutor, o qual "celebra a descodificação ilimitada nãodialética como libertação", o crescimento de forma descontrolada e sem rumo "do rizoma" como figura não estruturada e a "deterritorialização da máquina esquizofrénica." (p. 172-174). Para Han, "a patologia própria da positividade não é a infecção letal, senão o infarto", pois "a bulimia psíquica não se guia por um esquema imunológico, tendo em vista que não se gera nenhuma reação imune ao demasiado." (p. 173). "A máquina esquizo, liberada de toda negatividade", ressalta Han, "também gera uma violência da positividade", pois para ele "nem toda negatividade é destrutiva." Algumas forma de negatividade, como "a dúvida, a interrupção, o tédio, a espera ou a ira são construtivas, embora ameacem desaparecer em uma sociedade cada vez mais positivizada." (p. 177)

A Violência do Global (Capítulo 7) é analisada por Han tendo por interlocutores os escritos de Hardt e Negri. Para estes, "a globalização gera duas forças antagônicas", sendo que uma "cria o 'império', que dá lugar à ordem da dominação capitalista descentralizada e desterritorializada a partir de controles constantes e conflitos permanentes", enquanto a outra "produz uma 'multidão', um conjunto de singuilaridades que se comunicam entre elas e atuam conjuntamente através das redes." (p. 179). Na interpretação de Han, essa oposição entre as duas forças antagônicas feitas por Hardt e Negri não deixa de ser "uma nova versão da luta de classes", em que "a violência que gera o império se define como violência da exploração por parte do outro." (p. 179). Han não acredita que seja possível visualizar nesse esquema antagônico a ideia de que "o império" seja uma "classe dominante que explora a multidão como proletariado." (p. 180). Na sociedade contemporânea "a apatia e a indiferença, 
unidas a uma infantilização da sociedade cada vez maior, faz com que seja muito improvável uma atuação coletiva", pois "a egologização e a atomização da sociedade reduz radicalmente o espaço de uma atuação conjunta", o que impede "a construção de um contrapoder" que possa "realmente questionar a ordem capitalista." (p. 181). Para Han, "o espaço de violência e exploração já não geram uma oposição, tendo em vista que é você mesmo que se explora. [...] A exploração por parte do outro deixa lugar à auto exploração. Assim, se dá uma exploração sem dominação, que se desdobra em nome da liberdade." (p. 185). Trata-se da "imanência da violência" em que "a guerra chega à alma de cada um." (p. 186).

No último capítulo (Homo Liber), tendo por base os escritos do filósofo italiano Agamben, Han ressalta que "vivemos em uma sociedade dominada por um excesso de positividade" e de que "o terror da positividade talvez seja muito mais terrível que o terror da negatividade porque escapa a qualquer esquema de defesa imunológico." (p. 192). Já não temos um sujeito de obediência "submetido a uma instância de dominação que o obrigue a trabalhar e o explore", mas temos um "sujeito de rendimento" em que "a liberdade e a coação coincidem"; um sujeito que se "autoexpora" e cuja exploração "é mais eficiente que a exploração por parte de outro", pois "vem acompanhada de um sentimento enganoso de liberdade" em que a "exploração tem lugar sem dominação." (p. 193). Trata-se, por fim, de um sujeito "que equivocadamente se crê homo liber, que se imagina como soberano de si mesmo", mas na verdade "está submetido anátema do rendimento e se converte em homo sacer. $\bigcirc$ soberano da sociedade de rendimento é também o homo sacer de si mesmo." (p. 195).

As reflexões de Han em Topologia de la violencia certamente constituem um rico arsenal para pensar os dilemas e conflitos vivenciados na sociedade contemporânea. Além de dialogar com diversos autores de distintas áreas, Han apresenta uma amplo e complexo panorama do lugar da violência no cenário da sociedade atual. Uma boa leitura para educadores, pesquisadores, profissionais de distintas áreas e principalmente para todos aqueles que buscam compreender as novas e distintas patologias provocadas pela violência que se faz sentir nos micro e nos macros espaços da globalização. 


\section{REFERÊNCIA}

HAN, B.-C. Topología de la Violencia. Tradução Paula Kuffer. Barcelona: Herder, 2016.

Recebida em: 16 de março de 2018 Aceita em: 10 de abril de 2018

Endereço para correspondência: Rua Alfredo Chaves, 34, Lucas Araujo, 99074-270, Passo Fundo, Rio Grande do Sul, Brasil; mirafavero@gmail.com 